\title{
The research about "One Belt and One Road" platform logistics network layout
}

\author{
Hui He \\ Electronic Commerce Department of Business School \\ JiangXi Normal University,NanChang, China \\ hehui_1978@163.com
}

\begin{abstract}
Keywords: One Belt and One Road, logistics network, electronic commerce, strategic research Abstract. The rapid rise of the tertiary industry, especially in the information services industry, is gradually becoming the leading industry. The continuous improvement of the status of the internet, the convenience of the Internet and the arrival of information on the economic development of countries have had an important impact, which led to the rapid development of e-commerce. Now, In the environment of economic globalization and information globalization, countries are actively improving their e-commerce, and their role in the economic field is becoming more and more important. In the "One Belt and One Road" strategy, the development of cross-border electricity providers will face what kind of opportunities and challenges. Through the development of China's e-commerce status and its existing problems, combined with "One Belt and One Road". The development trend of e-commerce in China and the innovation of e-commerce model under the new economic norm with the margins.
\end{abstract}

\section{Introduction}

In September 2013, General Secretary Xi Jinping proposed for the first time to strengthen the "policy communication, road Unicom, trade flow and currency circulation and popular" to build the "Silk Road" strategic initiatives, and gradually improve into the current strategy. Cooperation and development for the concept and the initiative of the one way strategy through Asia and Africa non-continent, China's economy and the world economy linked to China's various fields will also quickly integrate into the world economic system. In this era background, the development of China's e-commerce will also usher in new opportunities and challenges. China's Entry into the New Situation of Deepening Reform and Opening-up in 2015 and the "New Normal" of Economic Development. A new era that "With the way" strategy in depth, establishment of the Asian infrastructure investment Bank, the RMB into the SDR basket to promote China into the "capital to go out" The transformation of the domestic economy from high growth rate to quality improvement, economic structure optimization and industrial innovation has become the core of rapid growth in the future economy. From the supply and demand on both sides of the reform to effectively demand the supply side to promote the concept of innovation, "Internet + " thinking, eliminate backward production capacity and create new economic growth point. The new trend of China's economic development and the new trend of international political and economic changes have created an unprecedented historical opportunity for China's supply chain logistics network to speed up overseas distribution and realize industrial structure optimization. Speed up the pace of globalization, in the node ports, traffic arteries and global trade and investment in the blue ocean regional layout, not only related to the optimization and integration of China's logistics enterprises, towards the professional, intelligent, cross-border logistics direction, and is conducive to change the logistics short China's economic development constraints, and related to China's overseas transport channel of high efficiency and safety.

\section{China's supply chain supply chain logistics network status and opportunities}

The year of 2016, is the logistics industry transformation and upgrading continue to deepen the year. In 2015, mobile Internet, 4G information channel driven by the rapid development of e-commerce, 
driven by China's traditional industries have a revolutionary subversion, supply chain logistics The network is no exception, and 2016 large economic environment conditions, the logistics industry has also entered another stage of development, although the logistics innovation has taken steps in the last year, but overall, logistics innovation on the whole society logistics efficiency Enhance the role of driving is not strong, the logistics industry innovation-driven development of the effect has not yet appeared, is just beginning.

\section{A: "One Belt and One Road" strategy for China's supply chain logistics network overseas development}

To create a huge market space "area along the way" strategy under the policy communication is conducive to reducing the supply chain logistics network overseas investment integrity and non-complete regulatory barriers; China Unicom will greatly promote China and the country along the transport infrastructure and communication facilities interoperability, supply chain logistics network in the country along the overseas layout to create a good hardware infrastructure, while nurturing a huge demand for engineering logistics services market and investment attraction; Trade flow and prosperity will bring the surge in cargo flow for China's supply chain logistics network overseas sustainable development to create a strong market demand; capital financing and preparation of the "two lines and a gold" will be China's supply chain logistics network overseas layout to provide strong financial support and financial risk prevention and protection; people connected to the supply chain logistics network layout to create a good social and public basis. According to the Ministry of Commerce and the General Administration of Customs statistics, from January to October 2015, China in the "one side along the way" 49 countries, non-financial investment totaled 1.31 billion US dollars, an increase of $36.7 \%$, accounting for China's non-financial $13.8 \%$ of the total foreign direct investment.

\section{B: The process of internationalization of the RMB to speed up the development of China's supply chain logistics network overseas}

To create a more favorable financial and monetary support RMB internationalization refers to the RMB across the border flow, becoming generally recognized pricing, trading and international reserve currency. The first, internationalization of the RMB to speed up in 2015 , the RMB cross-border payment system on the line; Second, the RMB officially joined the SDR basket. Although these two jobs will not directly contribute to the internationalization of the RMB, the RMB to the international goal of the key two steps. RMB internationalization trend will promote a series of supporting trade and investment settlement facilitation policies and procedures, China's supply chain logistics network in overseas investment in currency extraction and conversion procedures more convenient. RMB internationalization trend will increase the internal and external financing channels of overseas investment of logistics enterprises, reduce the cost of raising capital or capital transactions, and improve the efficiency of financing, so as to provide favorable financial guarantee for overseas investment and development of enterprises.

\section{C: Cross-border electricity business will become China's supply side reform of the new impetus} At present, China is a critical period of economic transformation and upgrading, but also "China made 2025" strategic planning implementation of the important layout period. In a number of occasions, General Secretary of Commerce has made it clear that this series of strategic objectives should be achieved smoothly. It is necessary to lose the opportunity to change the development ideas of the demand side only and to push forward the structural reform of the supply side in order to overcome the obstacles to the sustainable development of our economy The As mentioned earlier, through the "one by one" strategy, cross-border electricity business channel to resolve the excess capacity, is to reduce the constraints of the current economic restructuring of the effective burden of effective measures. To fundamentally consolidate China's industrial competitiveness, By improving the supply structure of economic development elements, to improve the efficiency of the elements of economic development, and then from the production supply side to correct China's international industrial chain in the low-end product surplus, high-end product supply structural imbalance. Today, in the "Internet + " good development trend, the traditional import and export trade model has been unable to 
fully meet the needs of enterprise economic development. The successful construction of the cross-border electricity business platform can make the traditional manufacturing industry quickly into the "Internet + " good development trend, to create a new carrier of an open economy, and vigorously enhance the use of international and domestic resources, two market capabilities, Type of economic development of new space. In the "one by one" strategy implementation, in addition to cross-border electricity through the platform to integrate domestic enterprises need to resolve excess capacity, make full use of the international market to boost domestic enterprises quickly and efficiently out of the product, but also through the effective integration of the platform Domestic high-quality enterprises with strong competitiveness of resources, so as to promote China's outstanding industrial clusters and global quality suppliers, service providers, overseas markets, and even government agencies for efficient docking, while China's industrial enterprises to provide financial, industrial 4.0, logistics, Data and other aspects of the service. Through the channel innovation, the domestic real economic enterprises can quickly obtain more open and multi-dimensional international economic and trade market, cross-border electricity business platform to make full use of foreign factors of production market, centralized procurement of domestic enterprises need to produce a variety of quality resources, On the basis for the manufacture of high-quality Chinese products to lay the foundation to help China's industrial and manufacturing out of the excellent "excellent way." This ensures the quality of production factors, from the source of production to achieve control, but also the current state to "supply side reform" to enhance the quality of China's international trade development should be the righteousness. This not only improves the efficiency of entering the international market, but also greatly reduces the cost of these enterprises to enter the international market. Cross-border electricity business will become an important platform for China to enhance economic openness After experiencing the impact of the world financial crisis, the new economic background under the background of China's economic growth from the past mainly rely on investment and resource consumption into innovation-driven, The establishment of a more sound new pattern of economic opening for the overall situation of China's economic development increasingly prominent. Therefore, not only to build a new pattern of development and support the development of the industrial system, innovative product production categories, but also must be innovative economic open path to enhance the open level.

\section{China's supply chain logistics network layout strategy}

China's supply chain logistics network layout to "take all the way" strategy to lead the national industrial trade pattern optimization and adjustment strategy as a guide to bilateral free trade agreement, international production cooperation, cross-border electricity business, foreign economic and trade cooperation area to promote "Internet + " and the combination of traditional logistics to form an intelligent, professional, global thinking for overseas layout, taking into account the national strategic interests and economic efficiency of enterprises, reasonable and orderly to promote and deploy.

\section{A: "One Belt and One Road" strategy along the national node port as the core, together with major projects}

Focus on the layout of the "one way" vision and action delineated the sea Silk Road two lines: one from China along the coast of the South China Sea, Malacca Strait, to the Indian Ocean, the Mediterranean; the other from the Chinese coastal by the South China Sea, through the Indonesian archipelago, to the south The Pacific Ocean. The 21st century Maritime Silk Road is a key port for the joint construction of smooth and efficient transport channel. The port is the fulcrum of marine transport, more than $90 \%$ of the international trade of the transport by sea, the continuous development of China's international trade trends and the import of important energy materials highly dependent on marine transport, so the marine strategic node port is the core of the supply chain logistics network overseas The In the "one way along the map" along the map, there are many in the core strategic position, but the economic development of the urgent need to develop the port city. For 
example, the port of Gwadar in Pakistan is located near the throat of the Persian Gulf, which is strategically important. It is only $400 \mathrm{~km}$ from the main channel of the global oil supply. The Strait of Hormuz is only Africa, Europe, the Red Sea, the Strait of Hormuz, the Persian Gulf Arrived in East Asia, is the Pacific region a number of important routes of the throat, Pakistan is one of the two major military ports.

\section{B: Relying on "Made in China 2025" strategy, the international production capacity strategy of rational distribution of supply chain network}

China's high-speed rail, nuclear power and other industrial layout overseas Chinese policy driven by the Chinese equipment "going out" is to promote China's industrial upgrading and economic growth and stability of the important strategy. Equipment "going out" strategy in the competitive advantage of the industry is high-speed rail and nuclear power. High-speed rail and nuclear power in the external cooperation is also constantly integrate industry resources, optimize the cooperation model, China's supply chain logistics network should take the initiative to incorporate high-speed rail and nuclear power overseas construction design, construction, equipment supply and operation and maintenance of the full range of service strategy in. As of the end of October 2015, at least nine countries have signed a clear cooperation agreement with China on the high-speed rail project, which is concentrated in the Southeast Asia Line, the Persian Gulf Red Sea Line, the American Line, the African Line and the European Line, which has a good Growing is the American line and "along the way" along the line. According to the demand for high-speed rail projects, China's supply chain logistics network should be in the layout of key routes for high-speed rail locomotives strong cargo, superior performance of the ship and other means of transport, in the key demand area port layout loading and unloading and land transportation company. Textile, steel, nonferrous metals, building materials, etc. or due to the loss of labor cost advantage, or due to overcapacity, upstream and downstream production line equipment for overseas investment, to achieve the transfer of the whole industry chain, industrial overseas transfer layout is generally concentrated in low labor costs, Resource-rich regions and countries.

\section{Conclusions}

Relying on foreign economic and trade cooperation area supporting the logistics service layout In the product "going out", construction and processing, resource utilization, agricultural processing and trade logistics of four types of parks, from the park supporting the warehousing, loading and unloading, import and export clearance, distribution to international transport, freight forwarding and other logistics services are covered. With the mature bonded area and special industrial park logistics service experience enterprises, the park can focus on the strategic industry joint venture to China's foreign economic and trade cooperation zone for the regional layout focus, to achieve with the park enterprises in China overseas development.

\section{Acknowledgements}

This work was financially supported by the Science and technology research project of Jiangxi Provincial Education Department (150370)

\section{References}

[1] M D Swaine. Chinese views and commentary on the 'One Belt, One Road'initiative[J]. China Leadership Monitor, 2015, 47: p.1-24.

[2] D U Debin, M A.Yahua One Belt and One Road: The grand geo-strategy of China's rise[J]. Geographical Research, 2015, 34(6): p.1005-1014.

[3] T.Winter One belt, one road, one heritage: Cultural diplomacy and the Silk Road[J]. The Diplomat, 2016, p. 29. 
[4] B R.Deepak One Belt One Road": China at the Centre of the Global Geopolitics and Geo-economics[J]. South Asia Analysis, 2014 p. 5838 